\title{
Making the most of the university campus for teaching ecology
}

\author{
Karen L Bacon ${ }^{1^{\star}}$ \& Julie Peacock ${ }^{1}$ \\ ${ }^{1}$ School of Geography, University of Leeds, LS2 9JT \\ ${ }^{*}$ Corresponding author: k.bacon@leeds.ac.uk
}

Keywords: field work; practical work; urban ecology; campus

\begin{abstract}
University campuses provide an accessible, cheap and useful means of teaching ecology to undergraduate students. We describe a short campusbased activity that was trialed in the 201516 academic year to engage first year physical geography students with both ecology and urban ecology. Students undertook a 40-minute investigation of the campus to identify niches and ecosystems and were asked to relate their findings to previous lecture material. Overall, the activity was enjoyed by students and considered useful by both students and staff in supporting students' engagement with ecology.
\end{abstract}

\section{Introduction}

Fieldwork is an essential part of a degree in geography, Earth sciences and ecology. In addition, it has been shown to be an effective pedagogic tool (Fuller, et al., 2006; Boyle et al., 2007, Maskall and Stokes, 2009). Field skills are an essential component of a student's training and is extremely important in providing students with specific skills required by employers (Andrews et al., 2003) in a variety of sectors; for example, environmental sciences, scientific consulting, ecology and geology, and form an important component of several occupations on the UK shortage occupation list.

At a time of rising student fees and tightening budgets across the university sector, an increasing emphasis is being placed on student satisfaction and the overall student experience (e.g. National Students Survey and upcoming Teaching Excellence Framework). It is essential that students develop a wide range of skills appropriate for future careers and essential for future student recruitment that NSS scores remain high and that students are enjoying and seeing the value in their undergraduate experience.

Fieldwork is often one of the highlights of the undergraduate experience and important for attracting and retaining students (Mauchline et al., 2013). However, fieldwork is often expensive for departments in terms of staff time and financial cost (Maskell and Stokes, 2009). It can present challenges for timetabling and can be difficult for students with caring responsibilities who cannot attend long days or residential trips. It can also create a barrier for students from lower income backgrounds if they are expected to contribute financially towards fieldtrips. 


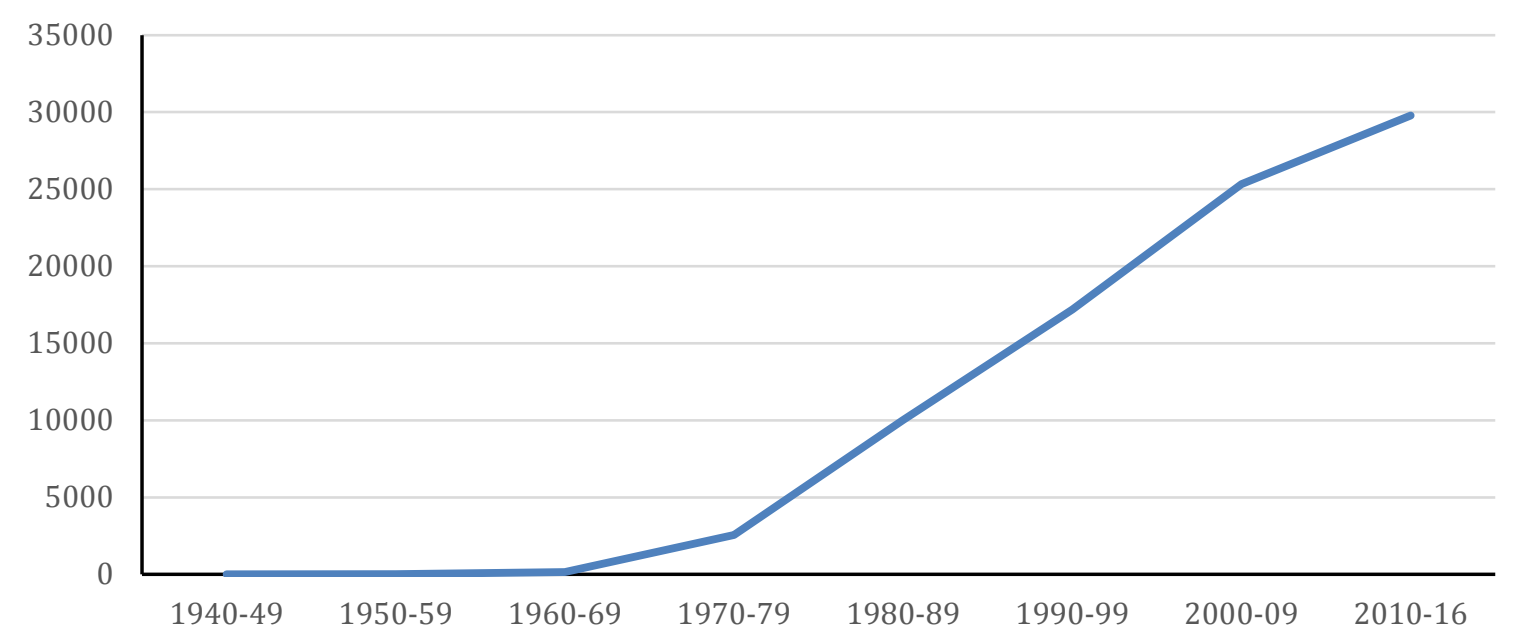

Figure 1 Number of entries in Web of Science publications that include the term "urban ecology' in their title or abstract by decade (source: Web of Science entries retrieved June 2016)

To overcome some of the issues associated with fieldwork many HEIs include campus based or very local field expeditions and have done so for a long time (for example Hess and Meierding, 1972; Jennings and Huber, 2003). Using the campus for fieldwork offers a range of benefits, including but not limited to, cheap (free), no (very limited) travel time, access to additional equipment and a reduction of "novelty effect" (see Cotton and Cotton, 2009). Using the university campus can be an end in itself - studying the ecology of the campus, used as an example for a particular learning outcome(s) e.g. leaf traits or building dichotomous keys - or it can be used as a training exercise to help students learn particular skills (e.g. taxonomy skills, quadrat analysis, surveying etc) in a familiar environment before employing and further developing these skills in a more exotic location.

In ecology the majority of very local or campus-based fieldwork, like traditional field trips, focuses on the natural environment and teaching around very urbanized areas has been limited. However, there has been a steady increase in research papers published on Urban Ecology over the last several decades, (Figure 1) and since 2008 over fifty percent of the Earth's population live in urban environments (United Nations DESA, 2008). In addition to this many students will be employed within the sustainability sector and the majority of jobs will focus on an urban setting. For these reasons it is important that students experience fieldwork in an urban setting and understand how ecosystem processes impact and are impacted on the urban environment.

Here we present a field session from a first year undergraduate module, 'Living Planet: Ecology and Evolution,' that introduced urban ecology as a new topic and linked it to many of the core concepts of general ecology.

\section{The Field Session}

Students on the module were first year Geography BSc undergraduates with mixed previous experience of ecology (some students have A-Level biology and geography while others only studied geography at school). The Ecology \& Evolution section of the Living Planet module moves students through the basics of ecology quickly, covering core concepts such as niche, population, ecosystems, functional ecology and other topics in the first six weeks before moving on to 
consider global ecological and evolutionary processes. Students are required to link the various topics together - for example, understanding the relevance of the "niche" ("the functional position of an organism in its environment, comprising the habitat in which the organism lives, the period of time during which it occurs and is active there and the resources it obtains there"; Allaby, 2010; Reece et al., 2011) to "biomes" ("[the] major life zones characterised by vegetation type, in terrestrial environments, and by the physical environment (e.g. light zones) in aquatic environments", Reece et al., 2011). This is something that some students have expressed difficulty with in the past.

In an effort to address this, students were offered the opportunity to take part in a one-hour session that used the campus as a field site to study urban ecology and to link the concepts that had been previously introduced in lectures to a real-world example. The University of Leeds campus provides an excellent environment in which to study urban ecology because it is within the city limits, close to the city centre, but also contains a wide variety of ecosystems and niches that are actively managed by the university. The active management of the campus includes a sustainability garden, bee hotels, bird boxes, roof gardens and other provisions to encourage biodiversity on campus. This range of ecosystems encourages a rich biodiversity on campus that is ideal for teaching ecology.

Students were provided with some brief online material that gave some details of urban ecology and were advised to review the previous lecture material before the session. Of the 92 registered students, 40 participated in the activity. Students worked in groups of 4-6 individuals and were provided with a campus map and a guidance worksheet. After a brief 5-minute introduction where students were given the details of their task and offered the opportunity to ask any questions, they were allotted 40 minutes to undertake the tasks outlined below in a self-guided walk with intermittent supervision.

Students were asked to undertake the following tasks:

1) Describe the ecology of the campus

2) What evidence for human influence do you observe?

3) What makes this an urban rather than a rural or natural environment?

4) What ecosystems are present?

5) What niches are present?

6) Are there any ecosystems or niches that are novel to this environment?

After the self-guided session, with staff support, students returned to the seminar room for a 20-minute discussion on the walk. Students discussed the ecosystems and niches that they had identified and what key features of the environment were urban in nature, sharing ideas and photos.

A week after the exercise, students were asked to complete a short questionnaire to assess the perceived usefulness of the trip. Answers were given in the form of a fivelevel Likert scale from 1. Not at all useful to 5. Very useful.

\section{Results and Discussion}

Thirty-two students returned completed questionnaires. The exercise was very well-received with all students recommending that the activity should be run again next year. Over $50 \%$ of students agreed that the activity had helped them to better understand some of the key concepts introduced in lectures and over $60 \%$ agreed that it had helped them to develop their understanding of urban ecology (see Table 1 for more detailed breakdown of questionnaire responses). Fieldwork has regularly been shown to aid students learning (Maskell \& Stokes, 2009), and thus these students' perceptions are to be expected. 


\begin{tabular}{|c|c|c|c|c|c|c|}
\hline Question & & 1 & 2 & 3 & 4 & 5 \\
\hline \multirow{2}{*}{$\begin{array}{l}\text { How useful was the pre-activity information in } \\
\text { preparing you for the activity }\end{array}$} & Female & - & - & $41 \%$ & $59 \%$ & - \\
\hline & Male & - & - & $50 \%$ & $50 \%$ & - \\
\hline \multirow{2}{*}{$\begin{array}{l}\text { Rate the usefulness of this activity for } \\
\text { developing your understanding of urban } \\
\text { ecosystems and ecology }\end{array}$} & Female & - & - & $36 \%$ & $59 \%$ & $5 \%$ \\
\hline & Male & - & - & $30 \%$ & $70 \%$ & - \\
\hline \multirow{2}{*}{$\begin{array}{l}\text { Rate the usefulness of this activity for your } \\
\text { understanding of ecological concepts (e.g. } \\
\text { ecosystems, relationships between different } \\
\text { organisms }\end{array}$} & Female & - & $9 \%$ & $32 \%$ & $36 \%$ & $23 \%$ \\
\hline & $\begin{array}{l}\text { Male } \\
\text { (one male } \\
\text { did not } \\
\text { respond) }\end{array}$ & - & $11 \%$ & $44 \%$ & $33 \%$ & $11 \%$ \\
\hline \multirow{2}{*}{$\begin{array}{l}\text { Rate how well you feel this activity } \\
\text { complimented the lecture topics of Living } \\
\text { Planet }\end{array}$} & Female & - & $9 \%$ & $18 \%$ & $59 \%$ & $14 \%$ \\
\hline & Male & - & - & $20 \%$ & $80 \%$ & - \\
\hline
\end{tabular}

Table 1 Breakdown of student responses to post-activity questionnaire. Students were asked to respond to the questions on a scale of 1 (not at all) to 5 (very much).

Reponses are given in percentage. Forty students took part in the activity, 32 completed questionnaires (22 female, 10 male).

Overall, the activity was enjoyed by the students and one student commented that there were 'good use of outside space for additional learning.' In addition, students agreed it helped them to identify links between the urban ecosystem and the theoretical information of the lectures. Indeed, one student commented that, 'learning the theory behind processes [in lectures] and then [1] understood them in practice in the lab and field.'

Staff on the module found this session aided the students in several ways. The activity provided students with a short field experience nested within traditional lecturing blocks and provided students with the opportunity to apply some of the theoretical learning to a field situation. Students answered lecturer questions well when out in the field e.g. "What niches can we see here? What suggests that where we are standing now is an urban environment?" and were able to link practical questions to theoretical lecture material. Students also engaged well with the lecturer in their small groups and asked far more questions than they tended to in lectures or workshop sessions on the module. Most indicated that they had enjoyed the activity. Several students also informally commented that they had not previously considered their local or campus ecology and had enjoyed seeing how the lecture concepts could be applied to the familiar environment of the university campus. One negative comment received from three students was that the worksheet could be better organised. This will be taken into account when the activity is run next and a modified, simpler worksheet will be developed.

In terms of organisation this session was simple to set up and the time taken to prepare was no more, or perhaps less than the traditional lecture slot it replaced. Although remaining on campus, a risk assessment had to be completed and students had to sign this in the same way as they would for a fieldtrip to more remote locations. This adds an additional level of 
administration for the session but can be recycled in future years, making it a minor start-up cost but not something that is likely to become burdensome in future years.

Staff also found that they had a greater opportunity to speak to small groups of students and explain or address misunderstandings of the material. Talking with small groups of students in sessions such as these is likely to have knock on effects with students finding staff more approachable and asking more questions in typical teaching sessions. In fact, the final session of the module several weeks after this session is a revision and Q\&A session, and the lecturers felt that students were more willing to ask questions this year than previously. This could simply be the cohort in question, but the more informal session may also have helped to make students more comfortable asking questions.

\section{Conclusion}

Overall, the session was considered successful. Students engaged well with the session and expressed satisfaction with the activities and learning outcomes. All participants recommended running the session in future years. Other lecturing staff on the module, aside from those who directly participated in it, were enthusiastic about the activity and thought that it helped to engage and enthuse students with the topic. Some consideration is currently being given to increasing this type of teaching for other sessions in the module.

\section{References}

Allaby, M. (2010) A Dictionary of Ecology. Oxford University Press, Oxford, UK.

Andrews, J., Kneale, P., Sougnez, W., Stewart, M. \& Stott, T. (2003). Carrying out pedagogic research into the constructive alignment of fieldwork. Planet Special Edition, 5, 51-52. Available at http://78.158.56.101/archive/gees/pubs/planet Ipse5back3.pdf
Boyle, A., Maguire, S., Martin, A., Milsom, C., Nash, R., Rawlinson, S. \& Conchie, S. (2007). Fieldwork is good: the student perception and the affective domain. Journal of Geography in Higher Education, 31 (2), 299-317. doi: $10.1080 / 03098260601063628$

Cotton, D. R. E. \& Cotton P.A (2009). Field biology experiences of undergraduate students: the impact of novelty space. Journal of Biological Education, 43:4, 169-174. doi: 10.1080/00219266.2009.9656178

Fuller, I., Edmondson, S., France, D., Higgitt, D. \& Ratinen, I. (2006). International perspectives on the effectiveness of geography fieldwork for learning. Journal of Geography in Higher Education, 30 (1), 89101. doi: 10.1080/03098260500499667

Hess, D. F., \& Meierding, T. (1972). The campus geology field trip. Journal of Geological Education, 20(3), 149-150.

Jennings, S.A., \& Huber, T. P., (2003). Campus-based geographic learning: A field orientated teaching scenario. Journal of Geography. 102(5), 185 - 192. Doi: $10.1080 / 00221340308978546$

Maskall, J. \& Stokes, A. (2009). Designing effective fieldwork for the Environmental and Natural Sciences. In GEES Teaching and Learning Guide. York, UK: HE Academy Subject Centre for Geography, Earth and Environmental Sciences.

Mauchline A. L., Peacock J.\& Park J. R. (2013). The Future of Bioscience Fieldwork in UK Higher Education. Bioscience Education 21, 7-19. doi: 10.11120/beej.2013.00014

Reece, J.B., Urry, L.A., Cain, M.L., Wasserman, S.A., Minorsky, P.V., and Jackson, R.B. 201. Campbell Biology. Pearson Education.

United Nations Department of Economic and Social Affairs (Population Division) 2008. World urbanization prospects: the 2007 revision. United Nations, New York. 